\title{
Leveraging Mega Events for Capacity Building in Voluntary Sport Organisations
}

\author{
Vassil Girginov ${ }^{1,2}$ (D) Nikolay Peshin ${ }^{3} \cdot$ \\ Lev Belousov ${ }^{3}$
}

Published online: 30 January 2017

(C) The Author(s) 2017. This article is published with open access at Springerlink.com

\begin{abstract}
Strengthening the work of national voluntary sport organisations (VSOs) is of strategic importance as they are considered custodians of their sport and have been entrusted with its governance, management of significant public funds and provision of services to a vast network of clubs and millions of participants. Using a mixed method approach, the study examined how VSOs in the UK and Russia leveraged the 2012 London and 2014 Sochi Olympics for capacity building. The political framing of the Games as a leverageable resource stimulated VSOs' engagement, but it was more on a tactical than strategic basis. Three main leveraging processes were employed by VSOs including aligning organisational objectives with the Games' strategic visions, using structured Olympic programmes and teaming up with a development partner. VSOs used the Games to enhance their organisational capacity in three areas of staff qualifications, organisational learning and performance management and created public value.
\end{abstract}

Résumé Le renforcement du travail des organismes sportifs bénévoles (OSB) a une importance stratégique puisqu'on considère qu'ils sont les gardiens de leur sport et dotés du mandat d'en assurer la gouvernance, de gérer d'importants fonds publics et d'offrir des services à un vaste réseau de clubs, ainsi qu'à des millions de participants. À l'aide d'une approche à méthode mixte, l'étude a examiné la façon dont les OSB du Royaume-Uni et de la Russie ont exploité les Jeux olympiques de Londres de 2012 et de Sochi de 2014 pour renforcer leurs capacités. En tant que ressource exploitable, le cadre politique des Jeux a stimulé l'engagement des OSB, et ce,

Vassil Girginov

vassil.girginov@brunel.ac.uk

1 Department of Life Sciences, Brunel University London, Uxbridge, UK

2 University of Johannesburg, Johannesburg, South Africa

3 Russian International Olympic University, Krasnodar, Russia 
plutôt sur le plan tactique que stratégique. Les OSB ont utilisé trois principaux processus d'exploitation, y compris l'alignement de leurs objectifs organisationnels sur les visions stratégiques des Jeux, l'utilisation de programmes olympiques structurés et la collaboration avec un partenaire du développement. Les OSB ont utilisé les Jeux pour rehausser leurs capacités organisationnelles dans trois secteurs des qualifications du personnel, soit la formation organisationnelle, la gestion du rendement et la valeur créée pour le public.

Zusammenfassung Die Förderung der Arbeit nationaler freiwilliger Sportorganisationen ist von strategischer Bedeutung, da sie als Wahrer des jeweiligen Sports betrachtet werden und mit dessen Regelung, mit der Verwaltung wichtiger öffentlicher Gelder sowie mit der Bereitstellung von Dienstleistungen an ein großes Netzwerk von Vereinen und Millionen von Teilnehmern betraut worden sind. Anhand eines Mixed-Methods-Ansatzes untersuchte die Studie, wie freiwillige Sportorganisationen in Großbritannien und Russland die Olympischen Spiele 2012 in London und 2014 in Sotschi zum Ausbau ihrer Kapazitäten nutzten. Das politische Rahmenwerk der Olympischen Spiele als eine ausbaufähige Ressource regte das Engagement der freiwilligen Sportorganisationen an; allerdings geschah dies eher auf einer taktischen als auf einer strategischen Basis. Die Organisationen wandten drei wichtige Ausbauprozesse an; darin eingeschlossen waren die Angleichung der organisatorischen Ziele an die strategischen Visionen der Olympischen Spiele, die Nutzung strukturierter olympischer Programme und der Zusammenschluss mit einem Entwicklungspartner. Die freiwilligen Sportorganisationen nutzen die Olympischen Spiele zum Ausbau ihrer organisatiorischen Kapazität in den Bereichen Mitarbeiterqualifikationen, organisatorisches Lernen und Leistungsmanagement und schufen einen öffentlichen Wert.

Resumen El fortalecimiento del trabajo de las Organizaciones Deportivas Voluntarias nacionales(VSO, por sus siglas en inglés) es de importancia estratégica ya que son consideradas custodios de su deporte y se les ha encomendado su gobernanza, la gestión de fondos públicos significativos, y la provisión de servicios a una amplia red de clubes y millones de participantes. Utilizando un enfoque de método mixto, el estudio examinó cómo las VSO en el Reino Unido y en Rusia aprovecharon las Olimpiadas de Londres 2012 y de Sochi 2014 para la creación de capacidad. El marco político de los Juegos como un recurso aprovechables estimuló el compromiso de las VSO, pero fue más de forma táctica que estratégica. Las VSO emplearon tres procesos de aprovechamiento principales, incluida la alineación de los objetivos organizativos con las visiones estratégicas de los Juegos, utilizando programas Olímpicos estructurados y formando equipo con un socio de desarrollo. Las VSO utilizaron los Juegos para aumentar su capacidad organizativa en tres áreas de cualificación del personal, el aprendizaje organizativo y la gestión del rendimiento y el valor público creado.

Keywords Capability $\cdot$ Leverageable resources $\cdot$ National voluntary sport organisations · Olympic Games · Organisational capacity · Organisational engagement 
National voluntary sport organisations (VSOs) have always been considered as a vehicle for achieving a range of non-sporting objectives including nation-building, promoting community wellbeing, economic development and improving health. A number of national and supranational policies have made explicit not only the role of sport in society, but also the need to refashion VSOs so they are fit partners for governments in the pursuit of various pro-social policy objectives (Coalter 2010, Groeneveld et al. 2011, Treasury 2002, LGID 2011).

Charging generally overstretched, underfunded and understaffed VSOs with wider policy objectives begs the question of whether they have the capacity to deliver the desired outcomes (Collins 2010; Houlihan and Green 2009). Unlike other non-profits, VSOs enjoy a unique position as the sole authority of an activity over a particular territory as well as being a conduit between developing sport nationally and globally. The local-global nexus presents VSOs with unparalleled opportunities to tap into a myriad of material and promotional resources through a system of major international competitions.

The appeal of mega sport events to national political and business elites for promoting various policy agendas is well-documented (Gold and Gold 2011; Müller 2015). UK developed a deliberate policy for hosting mega sport events and invested $£ 22$ million in bidding for them (UK Sport 2005, 2015). In 2016, the UK and Russia hosted over 80 and 70 major sport events, respectively. London staged the 2012 summer and Sochi the 2014 winter Olympic and Paralympic Games, which formed the context of the present study. The Olympic Games and other major events present a valuable resource, which can be strategically utilised to enhance the capacity of VSOs because they (i) have a liminoid character that is marked by a sense of celebration and camaraderie; (ii) can generate a sense of community and foster social interactions across groups, ages and geographical locations and (iii) can mobilise a great deal of public and private investments which otherwise might not be possible (Chalip 2006; Preuss 2004). VSOs' engagement with their internal and external environments is critical for building their organisational capacity and the ability to perform. The mobilising powers of mega events also allow for uniquely integrating the three main approaches to capacity building including capacity grants, development partner (i.e. how the capacity building intervention is delivered) and structured programmes (i.e. the nature of the intervention-short-long-term, narrowbroader focus), as identified by Blumenthal (2003).

Strengthening the work of VSOs is of strategic importance as they are considered custodians of their sport and have been entrusted with its governance, management of significant public funds, and provision of services to a vast network of clubs and millions of participants. Thus, they are expected to create public value. Between 2014 and 2017, Sport England and UK Sport invest some $£ 467$ million in 46 VSOs who are responsible for providing services to a vast network of an estimated 151,000 affiliated clubs and 15.5 million adult participants (Sport England 2015). Similarly, the Russian Ministry of Sport (RMS) provides some US\$400 million (2013-2020) to support the work of 100 accredited and 26 recognised VSOs serving some 30 million participants. VSOs and their members also play a multifaceted role in delivering the Games including selecting and training Olympic athletes, 
officiating, volunteering and supplying critical expertise for venues and competitions design.

This study brought together two distinct perspectives of leveraging mega sport events and organisational capacity building. In doing so, it placed capacity building in the specific context of the Olympic Games and addressed three interrelated questions:

(i) Why have the host VSOs engaged with the Olympics?

(ii) What leveraging processes were employed for building which capabilities?

(iii) What was the contribution of the Games for VSOs' capacity building?

\section{Conceptual Background}

\section{Approaches to Capacity Building in Non-profit organisations}

The study of organisational capacity has been enjoying a growing popularity since 2007 with an average of over 680 publications per year, of which $39 \%$ have been in business and only five percent in social sciences (Web of Knowledge 2016). Yet, commentators agree that the term remains elusive and theoretically homeless (Harrow 2001; Millar and Doherty 2016). Wigboldus et al. (2010) and Cairns, et al.'s (2005) analyses of capacity building noted its changing focus from institutions building in the $1950 \mathrm{~s}$ and $60 \mathrm{~s}$ to situation-tailored capacity development in the 2010s, as well as the resulting methodological difficulties in operationalising the concept.

The term capacity refers to the ability of an individual, organisation or a community to do something. It is a multidimensional concept which comprises both processes and structures as well as quantitative (e.g. presence of formal goals) and qualitative (e.g. staff evaluation regarding the achievements of those goals) dimensions (Sowa et al. 2004). Gazley and Christensen (2008) and Wigboldus et al. (2010) extensive analyses of the literature and De Vita et al. (2001) framework for studying non-profit organisations noted three contextual uses of capacity related to individual, organisational and nation-state levels. They also identified four main variables of capacity including human resources (e.g. motivation, knowledge base, experience), external (e.g. relationships, trust, domain logic), infrastructure (e.g. organisational culture, research, computers and IT) and financial (e.g. resources, assets, cost of labour). Capacity is also inseparable from the notion of capacity building as it is not a static property but one which is constantly evolving. Honadle (1981) suggested that while capacity describes the means to performance, capacity building describes the organisational efforts to improve organisational means. Cornforth and Mordaunt (2011) extended the two established approaches to understanding capacity building including "deficiency" and "empowering" with a third one called "engaging" capacity where organisations whose capacity is being developed play a greater role in selecting and managing the external help received as well as the capacity building process as a whole. 
Organisational capacity has received some treatment in sport literature but mainly with regards to community organisations (Breuer and Nowy 2015; Casey et al. 2012; Doherty et al. 2014; Edwards 2015; Millar and Doherty 2016, Schulenkorf and Edwards 2012; Sharpe 2006; Smith 2010). Gumulka et al. (2005), Misener and Doherty (2009), Doherty et al. (2014) and Breuer and Nowy (2015) have used Hall et al.'s (2003) multidimensional model of capacity which is concerned with financial, human and structural capacity, but they applied it only to the level of community organisations. As explicated by the above studies, these organisations are typically small, loosely structured and run largely by volunteers. Thus, they differ substantially from national VSOs in terms of their strategic orientation, responsibilities, size, structure, resources, level of formalisation and overall capabilities.

The present study built on Zinke's (2006) framework which saw capacity "as an emergent combination of attributes, assets, capabilities and relationships that enables an organisation and its members to perform, develop and self-renew and to create developmental value" (p. 4). Drawing on the extensive empirical work of the European Centre for Development Policy Management, it offered a more comprehensive understanding of capacity and its relevance to this research was threefold. First, borrowing from systems theory and conflict theory, Zinke's (2006) framework interpreted capacity as a system phenomenon and a collective ability rather than either individual or organisational one, which in combination produce outcomes greater than its individual parts. Furthermore, capacity emerged as a result of the interaction of various internal and external factors and is not always malleable to manipulations and rational planning. Millar and Doherty (2016) also developed a comprehensive process model for capacity building in non-profit sport organisations but for them it was a rational process guided by clear visions: "essentially capacity building, at its core, is rooted in strategic management...." (p. 371). The present study took the view that the ability to build capacity is a universal characteristic of all human systems, which is rooted in a commitment by people to better themselves. Because of its emerging and processual nature capacity is a potential state which may vary significantly across the same organisation over different periods. Second, for Zinke (2006), the main point of capacity is the creation of public value, which coincides with VSOs' role in society. Finally, this framework helped overcome a major limitation of other works, which subscribed to the view that capacity is about the ability to do something, but failed to explain what this aggregate meaning of ability might be.

Zinke proposed five core capabilities (i.e. collective skills) that make up the overall capacity of most organisations and systems including: (i) the capability to act, which reflects an organisation's identity and strategic intent to develop in a particular direction, and its motivation and commitment; (ii) the capability to generate development results concerns an organisation's ability to deliver services and to perform by improving its capacity, outputs and outcomes; (iii) the capability to relate captures how organisations relate to their context by competing for position, influence and resources; (iv) the capability to adapt and self-renew has to do with organisations' ability to manage change and to constantly innovate in response to environmental pressures and internal dynamics and (v) the capability to 
achieve coherence is indicative of the tension faced by organisations that pushes them to decide whether to specialise in a particular area, and how to differentiate from the competitors while retaining their coherence.

\section{Leveraging Mega Sport Events as a Means to Capacity Building}

There has been a burgeoning body of literature on legacies and leveraging of sport events as evidenced by the International Olympic Committee's (IOC) 20 pages long bibliography on the subject (IOC 2016). While legacy research tends to highlight the planning of possible outcomes of the event for different groups, studies on leveraging reverse the focus and emphasise how various organisations integrate the event in their strategic activities. There is a dearth of studies on national VSOs' use of major sports events for capacity building including a recent special issue of the European Sport Management Quarterly (2015, 15/1) on impacts and strategic outcomes from non-mega sport events. VanWynsberghe et al. (2011) study on the 2010 Vancouver Games and community capacity, and Taks et al. (2014) research on sport development outcomes (some of which could be considered as a form of capability) as a result of hosting a medium size international sport event were relevant to this research, but neither study examined VSOs and leveraging for capacity building.

Beesley and Chalip (2011, p. 324) argued that "a strategic approach to event planning and management, referred to as leveraging, not only can stimulate economic development, but also can be used to encourage change in social (Chalip 2004; Kellett et al. 2008) and environmental agendas (O'Brien and Chalip 2007a)". Olympic leveraging suggests that if this event is to deliver the espoused benefits, there is a need to move to a more strategic approach that considers in advance how host and non-host communities can derive sustainable benefits from the Games (Chalip 2014; Kellett et al. 2008). The ultimate purpose of leveraging involves "those activities that need to be undertaken around the event itself, which seek to maximize the long-term benefits from events" (Chalip 2004, p. 228).

O'Brien and Chalip's (2007b) model of leveraging mega events suggested that there are three types of leverageable resources including economic, social and environmental where each presupposes different strategic objectives and means of achieving them. This understanding of resources is rather abstract as it overlooks the fact that most resources cannot be utilised in their original form but through a process of resource development so they become more usable commodities. This entails entering into some sort of interactions between Olympic resources owners/ producers and VSOs so the symbolic value of the Olympics can be transformed into utility or exchange value. It follows that leverageable resources are to be found in the utility (e.g. feel good factor, sales) or exchange value provided by the event, as well as in the range of activities in the build up to and after it had finished. Honadle (1981) reinforced this point from a capacity building perspective by pointing out that although "inputs" in the form of resources such as personnel, revenue, information or community support are "grist for capable organizations" (p. 577), the real institutional strengths lie in the less tangible abilities of an organisation proactively to attract and absorb resources. Resource development and utilisation 
also allow VSOs to create public value as the ultimate point of capacity building. Leveraging in Olympic context thus represents a multidimensional form of capacity building concerned with an organisation's strategic intent and its ability to acquire resources, interact with the environment, position itself, manage change, deliver services and improve its performance. In agreement with Zinke (2006), leveraging, therefore, interpreted capacity both as a means and a developmental end in itself. While Zinke's and other conceptual frameworks recognise change as an element of capacity building, studying organisational change was beyond the scope of this research.

The present study, therefore, addressed an important gap in our knowledge and proposed interpreting mega events (i.e. a factor in Millar \& Doherty's 2016 model) not just as an occurrence in VSOs' calendar but as a resource, which could be variously utilised through a range of social interactions. Approaching capacity as a system phenomenon and a collective ability rather than either individual or organisational one allowed examining capacity building across individual, organisational and VSOs population levels. As far as can be ascertained, this has never been achieved before.

\section{Capacity Building in Context}

VSOs' capacity building in the UK and Russia has been shaped by national sport policies that promote two clear imperatives-winning more medals from major international competitions and being a fit partner to governments in delivering wider social and economic agendas (DCMS 2012; HM Government 2015; RMS 2013). The governments in both countries construed the Olympics as an opportunity to put in place a social contract by making an explicit commitment to use the Games to transform sport and societies (Girginov 2012). In the UK, the Games were seen as a unique occurrence fostering a number of social and economic interactions, and as an instrument for personal and social change (DCMS 2007). The Games were thus a resource to be leveraged, and this understanding was supposed to drive the strategic behaviour of various organisational actors. Russia viewed the Olympics as a celebratory event of the highest order, which naturally commanded a great deal of resources. From this point of view, the Games became a critical enabling factor for achieving the goals of the long-term national strategy for personal and sport development (Council of Ministers 2006, 2009). Gazley and Christensen (2008) and VanWynsberghe et al. (2011) pointed out the importance of understanding the context in which capacity is interpreted by organisations, which allowed framing leveraging the Games in the UK and Russia both as a means of capacity building and a specific capability.

The summer and winter Olympics presented very different leveraging opportunities for VSOs due to their scale, investment portfolio, media coverage and interactions. The geography of the host country also played an important role, and the farther a place was from the host city the lesser its involvement with the Games (Walton et al. 2008). Table 1 shows the basic metrics about the scale of the London and Sochi Games. 
Table 1 Scale of the 2012 London and 2014 Sochi Olympics

\begin{tabular}{lll}
\hline Indicator & London 2012 & Sochi 2014 \\
\hline Athletes & 10,500 Olympic & 2780 Olympic \\
Participating countries & 4269 Paralympic & 540 Paralympic \\
Sports played & 204 & 88 \\
& 26 Olympics & 7 sports 15 disciplines \\
Competition venues & 20 Paralympic & 5 sports 72 medal events \\
OCOG Games staff & 37 & 11 \\
Volunteers & 8635 & 9200 \\
Media personnel & 70,000 & 25,000 \\
TV audience (global) & 21,000 & 13,477 \\
Coverage across all platforms & 3.6 billion & 2.1 billion \\
Social media followers & $100,000 \mathrm{~h}$ & $11,700 \mathrm{~h}$ \\
Sponsorship (\$US) & 4.7 million & 2.2 million \\
Tickets sold & 1.1 billion & 1.3 billion \\
Cost including infrastructure (\$US) & 10.99 million & 1.1 million \\
\hline
\end{tabular}

Source IOC $(2012,2015 b)$ and own data

\section{Method}

A mixed method approach was adopted, which allowed combining the rich quantitative data about various aspects of organisational capacity (i.e. number of organisational members, affiliated clubs, sport participants, funding) with insights from key figures responsible for devising Games' leveraging strategies (i.e. interviews and observations). A sequential transformative design (Creswell et al. 2003) was employed where the two theoretical frameworks guided the study and the initial quantitative phase of the research was followed by a qualitative phase of observations and personal interviews with key officials. Chalip's (2004) and Zinke's (2006) frameworks informed the construction of the online survey and the interview guide. The research design enabled attending to the processual and structural dimensions and the three levels of capacity building including individual, organisational and community. There was no language barrier as the authors were fluent in English and Russian.

\section{Data Collection}

A comprehensive online survey was conducted with all 46 Sport England-funded and 100 Russian Ministry of Sport-funded organisations to gather the views of Olympic and non-Olympic sports. Without exception, these organisations promote an inclusive agenda and serve both able-bodied and people with disabilities. The UK questionnaire was administered in two stages-before the London Games in 
2011 and after them in 2014, while the Russian version only after the Sochi Games in 2015. The survey included 47 questions organised in 9 sections designed to capture the five core organisational capabilities and the corresponding capacity areas and leveraging activities (see Table 4). The response rate was $72 \%$ (36) in 2011, and 30\% (14) and 10\% (12) for the UK and Russian VSOs in 2014-2015, respectively. Given the overall small size of the population of VSOs, this response rate was considered satisfactory; moreover, the Russian sample included all winter Olympic VSOs.

Leveraging represents a strategic activity emanating from the top of the organisation, hence eleven in-depth interviews were conducted with the CEOs of Volleyball England (VE), British Gymnastics (BG), British Paralympic Association (BPA) and British Table Tennis Association for People with Disabilities (BTTAD), Director of Participation \& Partnership at British Cycling (BC), and the former head of research of Sport England and the presidents of Russian Figure Skating, CrossCountry Skiing, Luge and Snowboard Federations, and the Directors of Sport of Sochi 2014 and Education and Research at the Ministry of Sport. Organisations were selected on the basis of three main criteria that they represent: first, a wellstructured and successful Olympic VSO (i.e. cycling in UK and figure skating in Russia); second, a VSO of a "minority sport" (i.e. VE in UK and Snowboard in Russia) and third, a VSO of disability sport (i.e. BPA in UK and Special Olympics in Russia). Convenience and securing access to officials and documentation also affected the final selection of organisations. Interviews lasted between 60 and $130 \mathrm{~min}$ and were held in informants' offices, and with permission were tape recorded. Two potential limitations of the study included its sample of selected VSOs in each country for more in-depth analysis (there were 26 sports/VSOs on the summer and 7 on the winter Olympics), and the lack of a pre-Games survey in Russia.

Secondary sources gathered include VSOs and Organising Committees of the Olympic Games' (OCOG) reports and strategic plans, DCMS, Sport England and RMS policy documents and reports, IOC sessions and Executive Board archives and scientific databases. Strategic plans provided information about organisations' interpretation of their internal and external environments, main priorities and resource allocation approach (i.e. the capability to aspire and to achieve coherence and developmental results, and to relate), while reports enabled examining to what extent organisational aims had been achieved. Archival documents allowed tracking the evolution of 'leveraging thinking' within the main Olympic stakeholders. Data collection was complemented by visits to the IOC Headquarters in Lausanne. Discussions with four officials from the Sport and Legacy Departments provided useful insights into IOC's use of the Games for sport organisations' capacity building, and feedback on the study instrument.

\section{Data Analysis}

Notes and other materials generated through the field work were systematically analysed by the research team in an iterative process involving a critical dialogue with those involved in leveraging the Games. To keep the emic meanings an effort 
was made to avoid decontextualizing types of data for analysis. An interpretative thematic analysis (Robson 2011) was performed to identify the key themes with the aim not so much to explain the semantic content of the data but the identification of the underlying ideas, assumptions, conceptualisations and policies. The study followed a constructionist epistemology according to which meaning and experience are socially produced and reproduced, and which "seeks to theorise the sociocultural contexts, and structural conditions, that enable the individual accounts that are provided" (Braun and Clarke 2006, p. 91). The research questions and epistemological assumptions of the study dictated that theme identification had to be theoretical (i.e. deductive), as well as inductive in order to capture emerging themes. The analysis looked at how the five main theoretical themes (i.e. the capability to: act, generate development results, relate, adapt and self-renew and achieve coherence) played out across the data, and focused on them in coding the data. Table 4 shows the specific capacity areas and effects of leveraging, which also represent examples of coding data.

A two-stage process of document analysis was followed involving a superficial and thorough examination and interpretation of the texts (Bowen 2009). This iterative process combined elements of content analysis and thematic analysis. The analytic procedure used the above five analytic codes and involved selecting and appraising documents and notes. Content analysis helped organise the information into five categories pertinent to the central questions of this research. For example, revealing a VSO's ability to act allowed the research to identify the presumed relationship between an organisation's strategic intent and the resultant interactions responsible for utilising specific resources provided by the Games. Quantitative data were analysed by using descriptive statistics.

\section{Results and Discussion}

\section{VSOs Engagement with the Olympics}

Understanding why VSOs engaged with the Olympics allowed examining a central assumption of the study that capacity building could occur both as a result of rational strategic planning and as a more ad hoc activity. Over $80 \%$ of the UK and Russian VSOs expressed that the Games presented unique opportunities for the development of sport, but Russian summer sports saw no contribution of the Sochi Games for their development and the UK winter VSOs were equally sceptical about the contribution of London 2012. Differences were also apparent with regards to sport for people with disability. Only $54 \%$ of the UK and $30 \%$ of Russian VSOs used the inspirational effect of the Games to increase participation in sport for people with disability. These findings were consistent with the results of the 2011 UK study. Similar contrasting views are not unusual as the purported benefits of mega events are not greeted universally by everybody (Sadd 2013).

Harnessing the opportunities surrounding the Games presented a strategic puzzle because the Olympics belong to the IOC and are awarded to a host city under strict contractual terms only for a period of seven years (IOC 2015a). Hence, there is a 
need for a centrally coordinated approach to organisational engagement. The UK Government took two and four years after London was awarded the Games in 2005 to publish its Olympic and disability strategies, respectively (DCMS 2007, 2009). In Russia, the Games were seen as a critical component of the implementation of the long-term National Sport Development Programme (2006-2015), but apart from three bespoke programmes-elite athletes' preparation, volunteers and regional tourism - there was no Olympic strategy per se. Thus, the political framing of the Games, as a resource to be used for capacity building, was critical for its large-scale leveraging. Successful engagement with the Olympics in both countries presupposed employing all three of Blumenthal's (2003) capacity building approaches including capacity grants, development partner and structured programmes.

The two overriding reasons for VSOs' engagement with the Olympics were a sense of historical responsibility and an opportune occasion, neither of which was indicative of a clear strategic vision. First, there was a strong shared belief that the Games presented once in a lifetime opportunity for the host country to showcase its overall achievements including sport. This belief is closely related to an organisation's sense of identity, which is a key element of its capability to act (Zinke 2006). Second, VSOs' perception of the Olympics was exemplified by a BC official who remarked that "the London Olympics are the biggest free marketing campaign" (personal communications, 21 June 2015) and they wanted to take full advantage of this opportunity. This view was echoed by the RFSF's president: "the Games have significantly raised mass media's interest in our sport" (personal communications, March 3, 2015). Thirty-eight percent of the UK and $40 \%$ of Russian VSOs developed deliberate strategies for leveraging the Games, while the rest used more of a tactical/ad hoc approach by leveraging different programmes. For example, British Cycling did not need to see a national Olympic strategy to engage with the Games but others were less proactive, as the RCCSF's president explicated "no, we did not develop a dedicated Games' strategy" (personal communications, March 24, 2015). Evidence suggests that it was possible to develop organisational strategies in a new field (Casey et al. 2011) and that cities with a strategy for leveraging mega events received substantially more benefits than those without a strategy (Kellett, et al. 2008). Strategy development and implementation were the major challenges for both community organisations (Doherty, et al. 2014) and VSOs (Frawley et al. 2013) who tended to be preoccupied with day-to-day concerns.

VSOs in both countries used the Games to enhance their organisational capability in three core areas of staff qualifications $(60 \%$-UK; $80 \%$-Russia, i.e. capability to act), organisational learning $(50 \%$-UK; $80 \%$-Russia, i.e. capability to adapt) and performance management $(50 \%-\mathrm{UK} ; 90 \%$-Russia, i.e. capability to generate development results). Studies on community sport organisations echoed those findings by stressing the importance of building human capital (Wicker and Breuer 2013; Gomulka et al. 2006). VSOs' human resources made them irreplaceable in staging the Games and officials from VE, BC, BG, BPA, RCCSF and RFSF were involved in various aspects of event planning and execution. Thus, the Olympics presented rare opportunities for large-scale organisational learning, which Newman (2001) referred to as "catalytic capacity" concerned with three kinds of learning 
relationships including networks of colleagues and peers, coaches or mentors and experts. This study only partly supported the popular belief that the Games provide additional resources for sport. Only 15 and $20 \%$ of the UK and Russian VSOs, respectively, agreed that the Games provided a significant stimulus for the injection of increased funding into sport. The lack of additional investment in sport needed to stimulate various capabilities can be attributed to the Games' dual political role as a mobilizer of new resources and a (re)distributor of existing resources, as documented by Girginov and Hills (2008) in the UK context and Müller (2015) in Russia.

VSO-specific insights further illustrated their motivation for engagement with the Games. The BPA and BC approached the 2012 London Olympic and Paralympic Games with the reputation of highly successful organisations: BPA was ranked second at the previous three Olympics with 131, 94 and 102 medals, respectively, and $\mathrm{BC}$ was the most successful sport nationally and internationally after winning 34 medals including 25 gold at the 2008 Beijing Games.

Both VSOs expressed strategic intent to develop in a particular direction (i.e. the capability to act), and effectively utilised elite success as a resource to enhance other organisational capabilities. BPA's vision for London 2012 was twofold to win more medals across more sports than in Beijing, and to use the power of the Games to shift perceptions of disability sport and people with disability (BPA 2012). Ironically, BPA played no role in shaping the UK Government's Olympic disability strategy (DCMS 2009), because in the words of its CEO "due to the lack of organisational capacity BPA did not really get involved in discussions about this strategic document and its implementation" (personal communications, 15 April 2015).

BC identified two strategic priorities including diversification of sport and making cycling more appealing to commercial sponsors. Coupled with changes in governance and organisational culture, these priorities paved the way for a significant transformation of cycling, from an organisation capable of winning medals, to a sport, which provides opportunities to millions of people to socialise, improve their wellbeing and skills and to bring economic benefits to individuals and communities. In 2008, the organisation had a nation-wide membership of 24,000, a network of 1400 affiliated clubs and 150 staff, 20 partners and a budget of $£ 10$ million. In 2015 there were over 100,000 members (a 130\% growth since the Olympics), 1938 clubs, 254 staff, 80 partners and a £26 million budget (BC 2009, 2015).

The RCCSF concentrated on two strategic directions: strengthening the work with regional authorities with favourable winter conditions (i.e. the capability to relate) and ensuring involvement in the planning and development of the crosscountry skiing tracks and infrastructure at the highest level of decision making within OCOG (i.e. the capability to relate and achieve developmental results) (personal communications, March 21, 2015). As a result, the RCCSF received exposure to valuable organisational and technical expertise and national and international networks. Recognising RCCSF's expertise was considered to be of a particular value because, as its president explained "originally this type of expertise was sought outside Russia, but national experts were brought into correct many of 
the initial planning and implementation activities that had taken place" (personal communications, March 21, 2015).

RCCSF's athletes won five Olympic medals including one gold, which established them as role models who contributed to a marked increase of youth participation from 852,000 before Sochi to 859,000 a year later (RMS 2015). Staff involvement furthered the professionalisation of the organisation through establishing a pool of expertise. In combination, enhanced staff professionalism, role models and world-class facilities resulted in nurturing a forward organisational thinking within the RCCSF.

The RFSF approached the 2014 Sochi Games with three main priorities: to change its image from an underperforming organisation four years ago to a very successful one (i.e. the capability to act), to raise public interest in figure skating (i.e. the capability to relate) and to enhance the professional qualifications and management practices of all staff (the capability to achieve coherence) (personal communications, March 29, 2015). RFSF's priorities were supported by its National Development Programme (2010-2014) for the implementation of which the Games provided a powerful stimulus and additional resources. RFSF's athletes won four Olympic medals and became instant role models. The changing image of sport was critically facilitated by the extensive Olympic broadcast where figure skating drew the highest audience ratings displacing ice hockey as a number one TV sport. The live coverage of Russian figure skater Adelina Sotnikova's gold medal-winning performance was the highest rated broadcast of the Games, with an audience of 21.5 million viewers (IOC 2015b, p. 30). The Games reignited public interest in figure skating and helped grow the number of participants by $400 \%$ in 2015 (RMS 2015). The new state-of-the-art infrastructure was instrumental for delivering RFSF's intent to enhance staff qualifications and management practices. RFSF's strategic priorities also impacted on its capability to achieve developmental results by codifying staff's event management expertise into various know-how forms to be shared with the figure skating community (personal communications, 29 March, 2015).

\section{Leveraging Processes for Building Capabilities}

VSOs in both countries employed three main types of leveraging processes, similar to Blumenthal's (2003) capacity building approaches. The first type (i.e. capacity grant) included aligning Games opportunities with VSOs' strategic priorities and organisational learning, structures and governance. This entailed demonstrating a good fit between VSOs' strategic objectives and those of the Olympics for which they received large public and other grants. VSOs were largely successful in securing additional resources for supporting grassroots sport development (UK54\%; Russia-80\%); improving talent development and identification systems (UK$61 \%$; Russia-70\%) and enhancing chances for achieving international success (UK61\%; Russia-80\%). Less positive results transpired regarding securing increased funding for new and improved facilities (UK-42\%; Russia-20\%), equipment to support athletes' development (UK-54\%; Russia-15\%), and to develop outreach and participation products and services (UK-54\%; Russia-40\%). 
The second type of leveraging (i.e. structured programmes) concerned aligning VSOs with nation-wide Olympic programmes to ensure sustained organisational effects. There were eight such centrally managed programmes in the UK and six in Russia. The UK programmes were targeted towards particular groups and issues, while the Russian ones were more generic, but included one with a local focus on developing Sochi as a mountain sport resort, and one for training Sochi 2014 staff (RMS 2013). The UK's VSOs were heavily involved with the Games volunteering programme (Sport Makers-75\%), Sportivate (encouraging adult's mass participation legacy of the Games-100\%) and Gold Challenge (giving 14-25 years olds access to coaching courses-70\%). Russian's VSOs (87\%) were engaged with the Ministry of Sport-sponsored generic sports development programme, but $50 \%$ of them participated in the volunteers training and $56 \%$ in the preparation of national teams for the Games. The role of this leveraging process is reinforced by Edwards (2015, p. 10): "the management of community sporting events and programmes may be one of the most important link between sport and community capacity building".

The final leveraging process, (i.e. development partner) saw VSOs engaging with strategic partners nationally and internationally to promote sport and personal engagement. A limited number of VSOs collaborated with International Federation (IFs) to organise staff development courses (18\% UK; 44\% Russia), to pilot new projects (10\% and 12\%, respectively) and to establish pre-Games training camps (27 and 33\%, respectively). Significant differences emerged in VSOs' collaboration with regional and local authorities on Games-related sport development interventions. The UK's VSOs were more involved in promotional campaigns (82\%) and club development (50\%), while Russian's VSOs' engagement was limited to promotional campaigns (33\%). Marlier et al. (2015) highlighted the value of crosssector partnerships in building capacity for sport organisations and identified mutuality and policy support as the critical factors. Partnership building between government and non-profits in Russia would appear to be a more formalised process governed by over 250 normative acts (Sevortyan and Barchukova 2002).

The UK and Russian VSOs made consistent efforts to increase the positive media coverage of the whole sport (UK-69\%; Russia-80\%), disability sport (UK-61\%, Russia-26\%), elite athletes (UK-75\%, Russia-90\%) and public awareness (UK-77\%, Russia-90\%). There was a notable lack of coverage of disability sport in Russia, which was exactly the opposite in the UK. These findings echo Lovejoy and Saxton's (2012) observation that non-profits have been increasingly using social media not only for dissemination of information but also for forging community links and promoting action.

\section{Games Contribution to VSOs' Capacity Building}

The main contribution of the London and Sochi Olympics to capacity building was fourfold. First, the political framing of the Games, as a social contract, has challenged VSOs to think more strategically about the unique opportunities associated with this event. Second, the Olympics provided a powerful marketing tool for supporting ongoing organisational efforts. Third, the need for transforming 
Olympic resources into utility value stimulated, enhanced and coordinated organisational, social and economic interactions across different levels and constituencies. Finally, the Games enabled the process of capacity building through a greater state political and financial support to sport. This urged VSOs to extend their efforts aimed at improving the organisational means to performance. The state support in both countries was very different from the imperative institutional pressure exercised by the Canadian Government on national VSOs in the run up to the 1988 Calgary Olympics that led to both a greater organisational formalisation and many oscillations and reversals (Amis et al. 2004). The contribution of mega events to VSOs' capacity building, however, remains largely ignored by various frameworks for understanding Olympic legacy (e.g. Dixon et al. 2011; Preuss 2015) including the IOC's own Games impact study (IOC 2006).

Capacities at individual, organisational and community level were felt differently. At individual level, the range of UK beneficiaries was much greater than in Russia. In the UK, the main benefits were experienced by volunteers $(91 \%)$ followed by VSOs staff $(67 \%)$ and coaches $(67 \%)$. Athletes were the main beneficiaries in Russia (56\%) as well as referees (44\%) and to a lesser degree VSOs' staff $(33 \%)$. At organisational level, the Games helped enhance VSOs' infrastructure $(31 \%$-UK and $60 \%$-Russia) and the influence of the UK $(38 \%)$ and Russian (40\%) VSOs within IFs. Enhancing VSOs' standing internationally was a considerable achievement ensuring a stronger position in global sport policy affairs. Regarding community level, over two-thirds of the UK VSOs (62\%) and $70 \%$ of their Russian counterparts agreed that the Games were a major factor in inspiring more people to regularly participate in sport. Similar benefits, however, could be purely imagined than real because the evidence for the inspirational effect of the Olympics and their socioeconomic impacts has been inconclusive at best (Girginov 2015; Weed et al. 2009).

Tables 2 and 3 show the impact of the Olympics on VSOs' selected strategic and business areas. While establishing a causal link between Games' leveraging and increased sport participation is problematic, these findings suggest that some public value was created. Active engagement with learning and staff development activities yielded high positive impacts that were more pronounced in Russia than in the UK (Table 3), partly because of the significant state support for strengthening civic engagement (Buxton and Konovalova 2012).

\section{Leveraging Processes, Practices and Effects on VSOs' Capacity Building: Conclusions}

Table 4 summarises the relationship between VSOs' core capability areas, organisational capacity and the effects of leveraging the Games. VSOs' enhanced core capabilities resulted in greater effectiveness or capacity development in promoting sport. Olympic leveraging practices varied across the sample but allowed for some generalisations. The study revealed that internal capacity building processes within VSOs and their effects resulting from leveraging the Games were as important as the external ones such as increased sport participation that attracted 
Table 2 VSOs rating of the impact of the Olympics on their strategic areas (\%)

\begin{tabular}{|c|c|c|c|c|c|c|}
\hline \multirow[t]{3}{*}{ Strategic area } & \multicolumn{6}{|c|}{ Impact } \\
\hline & \multicolumn{2}{|l|}{ Low } & \multicolumn{2}{|c|}{ Medium } & \multicolumn{2}{|c|}{ High } \\
\hline & UK & Russia & UK & Russia & UK & Russia \\
\hline Growing sport participation & 36 & 30 & 64 & 0 & 0 & 70 \\
\hline Identifying sport talent & 36 & 40 & 64 & 40 & 0 & 20 \\
\hline Developing sport talent & 41 & 40 & 50 & 40 & 16 & 20 \\
\hline Achieving elite success & 25 & 0 & 36 & 60 & 41 & 40 \\
\hline Improving facilities and equipment & 50 & 33 & 41 & 45 & 9 & 22 \\
\hline
\end{tabular}

Table 3 VSOs rating of the impact of the Games on their business development (\%)

\begin{tabular}{|c|c|c|c|c|c|c|}
\hline \multirow[t]{3}{*}{ Business area } & \multicolumn{6}{|c|}{ Impact } \\
\hline & \multicolumn{2}{|l|}{ Low } & \multicolumn{2}{|c|}{ Medium } & \multicolumn{2}{|c|}{ High } \\
\hline & UK & Russia & UK & Russia & UK & Russia \\
\hline Staff development & 76 & 20 & 12 & 10 & 12 & 70 \\
\hline Revenue generation & 76 & 50 & 24 & 30 & 0 & 20 \\
\hline Organisational learning & 54 & 20 & 38 & 10 & 8 & 70 \\
\hline Performance management & 61 & 10 & 12 & 20 & 27 & 70 \\
\hline Innovation & 61 & 30 & 12 & 50 & 27 & 20 \\
\hline
\end{tabular}

much of legacy research. VSOs' organisational capabilities that were most positively affected included the capability to act by improving staff qualifications, organisational learning and processes; to relate through enhanced positive coverage of sport and the work of VSOs; to create aspirations for participation and excelling in sport, and to share know-how, as well as to generate developmental results through Games-generic and focused programmes. However, caution ought to be exercised when establishing a causal link between capacity and organisational effectiveness (Wing 2004), and as Herman and Renz (2008) warned, organisational effectiveness is a comparative, multidimensional social construct that is distinct from effectiveness at programme and network levels.

The UK examples revealed that both BC and BPA were able to significantly enhance their capability to act through organisational skills and human resource development, and the capability to adapt and self-renew by changing organisational structures and repositioning the image of their sport/organisation as a whole. They also illustrated the engaging capacity approach (Cornforth and Mordaunt 2011) where VSOs were able to use Games' capacity grants and structured programmes to improve their organisational performance while managing the capacity building process and organisational change. The Russian examples suggested that VSOs successfully changed the image of their sport and significantly enhanced staff 
Table 4 VSOs core capacity areas, organisational capabilities and effects of leveraging the Games

\begin{tabular}{|c|c|c|}
\hline $\begin{array}{l}\text { Core } \\
\text { organisational } \\
\text { capabilities }\end{array}$ & Capacity area & Effects of leveraging the Games \\
\hline \multirow[t]{2}{*}{ To act } & $\begin{array}{l}\text { Organisational skills } \\
\text { development }\end{array}$ & $\begin{array}{l}\text { Improving team work, information sharing, } \\
\text { budgeting and forecasting practices }\end{array}$ \\
\hline & $\begin{array}{c}\text { Human resources } \\
\text { development }\end{array}$ & $\begin{array}{l}\text { Enhancing VSOs staff/volunteers involvement with } \\
\text { the Games; skills development }\end{array}$ \\
\hline \multirow[t]{2}{*}{$\begin{array}{l}\text { To adapt and } \\
\text { self-renew }\end{array}$} & $\begin{array}{l}\text { Organisational structure } \\
\text { development }\end{array}$ & $\begin{array}{l}\text { Strengthening commitment to organisational } \\
\text { mission, introducing new strategic orientation, } \\
\text { and planning practices; Repositioning VSOs from } \\
\text { an organisation to a sport; running national } \\
\text { promotional campaigns; growing participation } \\
\text { and improving talent identification and elite } \\
\text { success pathways }\end{array}$ \\
\hline & Knowledge creation & $\begin{array}{l}\text { Greater use of research and technology to enhance } \\
\text { organisational and athletes' performance and } \\
\text { participants' experience }\end{array}$ \\
\hline $\begin{array}{l}\text { To achieve } \\
\text { coherence }\end{array}$ & Governance & $\begin{array}{l}\text { Improving governance structures, growing VSOs' } \\
\text { constituency, advocacy base, accountability and } \\
\text { relations with stakeholders }\end{array}$ \\
\hline $\begin{array}{l}\text { To generate } \\
\text { development } \\
\text { results }\end{array}$ & $\begin{array}{l}\text { Aspirations creation systems } \\
\text { and infrastructure building }\end{array}$ & $\begin{array}{l}\text { Aligning with Games specific programmes; Forging } \\
\text { links with: IF (e.g. hosting staff development } \\
\text { courses, piloting national/international initiatives, } \\
\text { pre-Games training camps); regional and local } \\
\text { Olympic strategies (e.g. Cultural programme); } \\
\text { with commercial organisations (e.g. tapping into } \\
\text { global and national Olympic sponsors' activation } \\
\text { budgets); Enhancing opportunities for } \\
\text { participation and better sport experiences }\end{array}$ \\
\hline To relate & $\begin{array}{l}\text { Relate to organsational } \\
\text { context; Compete for } \\
\text { resources }\end{array}$ & $\begin{array}{l}\text { Raising general awareness and creating positive } \\
\text { discourses and dispositions for participation, } \\
\text { excelling and winning Olympic medals; } \\
\text { promoting achievement culture }\end{array}$ \\
\hline
\end{tabular}

professionalism, which resulted in improved service capabilities. Our findings presented capacity as an emerging property and a potential state and supported Baser and Morgan's (2008, p. 20) observation that "capacity development involves the transitioning from one pattern or configuration of behaviour to another. As such, it is fundamentally about the dynamics of change-organisational, institutional, personal, political and logistical". This research also revealed that change did not always occur as a result of a clearly formulated strategy but could be caused by the interplay between various internal and external factors. Thus, it provided support for Zinke's (2006) notion of capacity building as only partially open to engineering.

The study elucidated the contribution of the Games to the three levels of capacity building. At individual level, the main beneficiaries were VSOs' staff including administrators, volunteers, referees, coaches and technical personnel. Differences between the main beneficiaries in the UK and Russia could be attributed to the 
different sport models of those countries. Sport in the UK is rooted in a club system (Keech 2013), which provides a natural home to volunteers, while Russian sport is organised around regional structures and specialised sport schools (Platonov 2010). There was limited evidence for transforming individual gains into organisational.

At organisational level, the strategic leveraging of the Games resulted in improved organisational governance and structures. At community level, significant changes were observed in the image of sport (e.g. BC and RFSF) and enhanced overall sense of pride among the community of VSOs, as well as a capacity for leveraging opportunities in the post-Games period (e.g. BPA and RCCSF). Capacity building through leveraging mega sport events at these three levels enhanced the ability of VSOs to create public value.

The comparison between the UK and Russian VSOs revealed the relationship between the political framing of mega sport events, the main leveraging mechanisms employed by these organisations and the capacity building processes taking place across individual, organisational and community levels. The study transcended the strategic imperative behind capacity building that dominates current literature and viewed it as a universal characteristic of all human systems. This allowed it to offer a more detailed explanation of what VSOs' abilities mean in practice. Thus, it showed that capacity building is not merely a means for developing organisational performance but a desirable end in itself. The study also challenged the current mega events legacy orthodoxy concerned with externally measurable tangible and largely 'unanimous' outcomes such as the number of competitions, participants and jobs created, and turned the gaze to equally valuable internal processes of building individual and organisational capacities. Finally, it offered some transferable lessons from VSOs' engagement with mega sport events that can be used to inform policy making and organisational planning in the voluntary sector in different cultural contexts. Future research would benefit from a comprehensive examination of the leveraging processes before, during and after not only major sport events but also other culturally and socially significant events that involve non-profit organisations. Following the conceptualisation of capacity as a system phenomenon, there is also a need to better capture the interplay between capacity building at individual, organisational and community levels.

Acknowledgement The authors would like to thank the International Olympic Committee Olympic Studies Centre Advance Research Grant programme for the financial and logistical support in conducting the study. We also would like to thank the three unanimous reviewers for their constructive comments on the earlier draft of this paper.

Conflict of interest The authors declare that they have no conflict of interest.

Open Access This article is distributed under the terms of the Creative Commons Attribution 4.0 International License (http://creativecommons.org/licenses/by/4.0/), which permits unrestricted use, distribution, and reproduction in any medium, provided you give appropriate credit to the original author(s) and the source, provide a link to the Creative Commons license, and indicate if changes were made. 


\section{References}

Amis, J., Slack, T., \& Hinings, R. (2004). The pace, sequence, and linearity of radical change. Academy of Management Journal, 47(1), 15-39.

Baser, H., \& Morgan, P. (2008). Capacity, change and performance. Study Report. Discussion Paper No.59B. Maastricht: European Centre for Development Policy Management.

Beesley, L., \& Chalip, L. (2011). Seeking (and not seeking) to leverage mega-sport events in non-host destinations: The case of Shanghai and the Beijing Olympics. Journal of Sport \& Tourism, 16(4), 323-344.

Blumenthal, B. (2003). Investing in capacity building: A guide to high-impact approaches. New York: The foundation Centre.

Bowen, G. (2009). Document analysis as a qualitative research method. Qualitative Research Journal, 9(2), 27-40.

Braun, V., \& Clarke, V. (2006). Using thematic analysis in psychology. Qualitative Research in Psychology, 3(2), 77-101.

Breuer, C., \& Nowy, T. (2015). A comparative perspective on European football Organizational capacity of European football clubs. Köln: Deutsche Sporthochschule Köln.

British Cycling. (2015). Annual Report. Manchester: BC.

British Cycling. (2009). Annual Report. Manchester: BC.

British Paralympic Association. (2012). Maximizing momentum. London: BPA.

Buxton, C., \& Konovalova, E. (2012). Russian civil society: History, today, and future prospects. Moscow: International NGO Training and Research Centre.

Cairns, B., Harris, M., \& Young, P. (2005). Building the capacity of the voluntary nonprofit sector: Challenges of theory and practice. International Journal of Public Administration, 28(9-10), 869-885.

Casey, M., Harvey, J., Eime, R., \& Payne, W. (2012). Examining changes in the organisational capacity and sport-related health promotion policies and practices of State Sporting Organizations. Annals of Leisure Research, 15(3), 261-276.

Casey, M., Payne, W., \& Eime, R. (2011). Organisational readiness and capacity building strategies of sporting organisations to promote health. Sport Management Review, 15(1), 109-124. doi:10.1016/j. smr.2011.01.001.

Chalip, L. (2004). Beyond impact: A general model for host community event leverage. In B. W. Ritchie \& D. Adair (Eds.), Sport tourism: Interrelationships, impacts and issues (pp. 226-252). Clevedon: Channel View.

Chalip, L. (2006). Towards social leverage of sport events. Journal of Sport \& Tourism, 11(2), 109-127.

Chalip, L. (2014). From legacy to leverage. In J. Grix (Ed.), Leveraging legacies from sport mega-events (pp. 2-13). Basingstoke: Palgrave.

Coalter, F. (2010). The politics of sport-for-development: Limited focus programmes and broad gauge problems? International Review for the Sociology of Sport, 45(3), 295-314.

Collins, M. (Ed.). (2010). Examining sports development. London: Routledge.

Cornforth, C., \& Mordaunt, J. (2011). Organisational capacity building: Understanding the dilemmas for foundations of Intervening in small-and medium-size charities. Voluntas: International Journal of Voluntary Nonprofit Organizations, 22(3), 428-449.

Council of Ministers. (2006). Federal programme-development of physical culture and sport in Russia 2006-2015. Moscow: CM. (in Russian).

Council of Ministers. (2009). Strategy for the development of physical culture and sport in Russia until 2020. Moscow: CM. (in Russian).

Creswell, J. W., Plano Clark, V. L., Gutmann, M. L., \& Hanson, W. E. (2003). Advanced mixed methods research designs. In A. Tashakkori \& C. Teddlie (Eds.), Handbook of mixed methods in social and behavioral research (pp. 209-240). Thousand Oaks, CA: SAGE.

DCMS. (2007). Our promise for 2012: How the UK will benefit from the Olympic \& Paralympic Games. London: DCMS.

DCMS. (2009). London 2012: A legacy for disabled people: Setting new standards, changing perceptions. London: DCMS.

DCMS. (2012). Creating a sporting habit for life. London: DCMS. 
De Vita, C., Fleming, C., \& Twombly, E. (2001). Building nonprofit capacity: A framework for addressing the problem. In C. De Vita \& C. Fleming (Eds.), Building capacity in nonprofit organisations (pp. 209-240). Washington, DC: Urban Institute.

Dixon, T., Benson, A., \& Blackman, D. (2011). Developing a framework for evaluating Olympic and Paralympic legacies. Journal of Sport \& Tourism, 16(4), 285-302.

Doherty, A., Misner, L., \& Cuskelly, G. (2014). Towards a multidimensional framework of capacity in community sport clubs. Nonprofit and Voluntary Sector Quarterly, 43(25), 1245-1425.

Edwards, M. (2015). The role of sport in community capacity building: An examination of sport for development research and practice. Sport Management Review, 18(1), 6-19.

England, Sport. (2015). Active people. London: Sport England.

Frawley, S., Toohey, K., \& Veal, A. (2013). Managing sport participation legacy at the Olympic Games. In S. Frawley \& D. Adair (Eds.), Managing the Olympics (pp. 66-83). London: Palgrave.

Gazley, B., \& Christensen, R. (2008). Capacity for public administration: Analysis of meaning and measurement. Public Administration and Development, 28(4), 265-279.

Girginov, V. (2012). Governance of London 2012 Olympic sport legacy. International Review for the Sociology of Sport, 47(3), 1-16.

Girginov, V. (2015). Has the London 2012 Olympic Inspire programme inspired a generation? A realist view. European Physical Education Review, 22(2), 1-17. doi:10.1177/1356336X15623169.

Girginov, V., \& Hills, L. (2008). The 2012 London Olympic Games and participation in sport: Understanding the link. The International Journal of the History of Sport, 25(14), 2091-2116.

Gold, J., \& Gold, M. (2011). Olympic cities: City agendas, planning, and the world's Games, 1896-2016. London: Routledge.

Groeneveld, M., Houlihan, B., \& Ohl, F. (Eds.). (2011). Social capital and sport governance in Europe. London: Routledge.

Gumulka, G., Barr, C., Lasby, D., \& Brownlee, B. (2005). Understanding the capacity of sports \& recreation organizations: a synthesis of findings from the national survey of nonprofit and voluntary organizations and the national survey of giving, volunteering and participating. Toronto: Heritage Canada.

Hall, M. H., Andrukow, A., Barr, C., Brock, K., de Wit, M., Embuldeniya, D., et al. (2003). The capacity to serve. Toronto, ON: Canadian Centre for Philanthropy.

Harrow, J. (2001). Capacity building as a public management goal. Public Management Review, 3(3), 209-230.

Herman, R., \& Renz, D. (2008). Advancing nonprofit organizational effectiveness research and theory: Nine theses. Nonprofit Management \& Leadership, 18(4), 399-415.

HM Government. (2015). Sporting future. A new strategy for an active nation. London: DCMS.

Hondale, B. (1981). A capacity-building framework: A search for concept and purpose. Public Administration Review, 41(5), 575-580.

Houlihan, B., \& Green, M. (2009). Modernization and sport: The reform of sport England and UK sport. Public Administration, 87(3), 678-698.

International Olympic Committee. (2006). What is the Olympic Games global impact study?. Olympic Review, 6, 1-2.

International Olympic Committee. (2012). London 2012 marketing report. Lausanne: IOC.

International Olympic Committee. (2015a). Sochi 2014 marketing report. Lausanne: IOC.

International Olympic Committee. (2015b). Host city contract. Retrieved March 22, 2015 from https:// stillmed.olympic.org/Documents/Host_city_elections/Host_City_Contract_Principles.pdf.

International Olympic Committee. (2016). Olympic Games: legacies and impacts (2015). Bibliography. Lausanne: IOC.

Keech, M. (2013). The organization of sport in the United Kingdom. In C. Sorby (Ed.), Sport governance in the world. A socio-historic approach (pp. 467-496). Paris: Editions Le Manuscrit.

Kellett, P., Hede, A.-M., \& Chalip, L. (2008). Social policy for sport events: Leveraging (relationships with) teams from other nations for community benefit. European Sport Management Quarterly, $8(2), 101-121$.

Local Government Improvement and Development (LGID). (2011). Building capacity in culture and sport civil society organisations. London: LGID.

Lovejoy, K., \& Saxton, G. D. (2012). Information, community, and action: How nonprofit organizations use social media. Journal of Computer-Mediated Communication, 17(3), 337-353. 
Marlier, M., Lucidarme, S., Cardon, G., De Bourdeaudhuij, I., Babiak, K., \& Willem, A. (2015). Capacity building through cross-sector partnerships: a multiple case study of a sport program in disadvantaged communities in Belgium. BMC Public Health, 15, 1306.

Millar, P., \& Doherty, A. (2016). Capacity building in non-profit sport organisations: Development of a process model. Sport Management Review, 19(4), 365-377.

Misener, K., \& Doherty, A. (2009). Case study of organizational capacity in nonprofit community sport. Journal of Sport Management, 23(4), 457-482.

Müller, M. (2015). After Sochi 2014: costs and impacts of Russia's Olympic Games. Eurasian Geography and Economics, 55(6), 628-655.

Newman, A. (2001). Built to change: Catalytic capacity building in non-profit organizations. A sabbatical report submitted to the David and Lucile Packard Foundation and The Nature Conservancy.

O’Brien, D., \& Chalip, L. (2007a). Executive training exercise in sport event leverage. International Journal of Culture, Tourism and Hospitality Research, 1(4), 296-304.

O'Brien, D., \& Chalip, L. (2007b). Sport events and strategic leveraging: Pushing towards the triple bottom line. In A. G. Woodside \& D. Martin (Eds.), Tourism management: Analysis, behavior, and strategy (pp. 318-338). Cambridge: CABI.

Platonov, N. (2010). High performance sport and preparation of national team for the Olympic Games. Moscow: Soviet Sport. (In Russian).

Preuss, H. (2004). The economics of staging the Olympic: a comparison of the Games 1972-2008. Cheltenham Glos: Edward Elgar.

Preuss, H. (2015). A framework for identifying the legacies of a mega sport event. Leisure Studies, 34(6), 627-642. doi:10.1080/02614367.2014.994552.

Robson, C. (2011). Real world research (3rd ed.). Chichester: Wiley.

Russian Ministry of Sport (RMS). (2013). Annual sport report. Moscow: RMS. (in Russian).

Russian Ministry of Sport (RMS). (2015). Annual sport report. Moscow: RMS. (in Russian).

Sadd, D. (2013). Protesting the Games. In V. Girginov (Ed.), Handbook of the London 2012 Olympic and Paralympic Games: Celebrating the Games (pp. 227-238). London: Routledge.

Schulenkorf, N., \& Edwards, D. (2012). Maximizing positive social impacts: Strategies for sustaining and leveraging the benefits of intercommunity sport events in divided societies. Journal of Sport Management, 26(5), 379-390.

Sevortyan, A., \& Barchukova, N. (2002). The nonprofit sector and government in the Russian regions: Patterns and prospects for collaboration. Moscow: Charities Aid Foundation.

Sharpe, E. (2006). Resources at the grassroots of recreation: Organizational capacity and quality of experience in a community sport organization. Leisure Sciences: An Interdisciplinary Journal, 28(4), 385-401.

Smith, A. (2010). Leveraging benefits from major events: Maximising opportunities for peripheral urban areas. Managing Leisure, 15(3), 161-180.

Sowa, J., Selden, S., \& Sandfort, J. (2004). No longer immeasurable? A multidimensional integrated model of nonprofit organizational effectiveness. Nonprofit and Voluntary Sector Quarterly, 33(4), $711-728$.

Sport, U. K. (2005). Hosting major sport events. London: UK Sport.

Sport, U. K. (2015). Gold framework. London: UK Sport.

Taks, M., Green, C., Misener, L., \& Chalip, L. (2014). Evaluating sport development outcomes: The case of a medium-sized international sport event. European Sport Management Quarterly, 14(3), 213-237.

Treasury, H. M. (2002). The role of the voluntary and community sector in service delivery: A cross cutting review. London: HM Treasury and Compact Working Group.

VanWynsberghe, R., Kwan, B., \& Van Luijk, N. (2011). Community capacity and the 2010 Winter Olympic Games. Sport in Society, 14(3), 370-385.

Walton, H., Longo, A., \& Dawson, P. (2008). A contingent valuation of the 2012 London Olympic Games. Journal of Sports Economics, 9(3), 304-317.

Web of Knowledge. (2016). Web of science. Retrieved from Thomson Reuters http://wcs. webofknowledge.com.ezproxy.brunel.ac.uk/RA/analyze.do.

Weed, M., et al. (2009). A systematic review of the evidence base for developing a physical activity and health legacy from the London 2012 Olympic and Paralympic Games. London: Department of Health. 
Wicker, P., \& Breuer, C. (2013). Exploring the organizational capacity and organizational problems of disability sport clubs in Germany using matched pairs analysis. Sport Management Review, 17(1), 35-48. doi:10.1016/j.smr.2013.03.005.

Wigboldus, S., Nell, A.-J., Brouwer, H., \& van der Lee, J. (2010). Making sense of capacity development. Wageiningen: Wageiningen UR Centre for Development Innovation.

Wing, K. T. (2004). Assessing the effectiveness of capacity-building initiatives: Seven issues for the field. Nonprofit and Voluntary Sector Quarterly, 33(1), 153-160.

Zinke, J. (2006). European Centre for Development Policy Management Study on Capacity, Change and Performance-Final Workshop. Workshop report. Maastricht, 15-17 May 2006. 